\title{
Chronic Tumor Necrosis Factor- $\alpha$ Infusion in Gravid C57BL6/J Mice Accelerates Adipose Tissue Development in Female Offspring
}

\author{
Suzan Lambin, MSc, Rita van Bree, MLT, Ignace Vergote, MD, PhD, and \\ Johan Verhaeghe, MD, PhD
}

\begin{abstract}
OBJECTIVE: Tumor necrosis factor (TNF)- $\alpha$ is thought to mediate, in part, the link between obesity and insulin resistance, and women with gestational diabetes mellitus (GDM) have raised serum TNF- $\alpha$ concentrations. Our objective was to investigate whether systemic TNF- $\alpha$ administration into gravid C57BL6/J mice causes a GDM-like syndrome and affects growth and adipose tissue (AT) development in the offspring.

Methods: We assessed glucose tolerance and reproductive outcome in mice infused with saline, or $2 \mu \mathrm{g}$ or $4 \mu \mathrm{g}$ recombinant mouse (rm)TNF- $\alpha$ by subcutaneous mini-osmotic pumps between days (d) 11.5 and 18.5 of gestation. Subsequently, we studied the effects of the $2-\mu \mathrm{g}$ dose on maternal AT metabolism. Finally, the growth of offspring exposed to $2 \mu \mathrm{g} r m T N F-\alpha$ in utero was followed until 8 weeks postnatal age. At 8 weeks, we assessed $A T$ accumulation, as well as adipocyte area in white $A T$ and insulin sensitivity in males, and adipokine $m R N A$ levels in various $A T$ depots in females.

Results: The peak glucose response to an intraperitoneal glucose stimulus in late-gravid mice and fetal weight were higher with $2 \mu \mathrm{g}$ but not $4 \mu \mathrm{g} r m T N F-\alpha$ compared with saline; however, $2 \mu \mathrm{g} T N F-\alpha$ did not affect AT parameters. The female but not male offspring of these mice showed accelerated growth, hyperadiposity, robustly increased leptin expression in all AT depots, and raised fasting blood glucose.

Conclusions: TNF- $\alpha$ infusion ( $2 \mu \mathrm{g}$ for 7 days) in gravid mice resulted in a mild GDM syndrome and accelerated $A T$ development in the offspring in a sex-specific manner. The data suggest that TNF- $\alpha$ mediates in part the effects of GDM on fetal growth and postnatal adiposity, and constitutes a potential mediator of intrauterine programming. (J Soc Gynecol Investig 2006;13:558-65) Copyright (C) 2006 by the Society for Gynecologic Investigation.
\end{abstract}

KeY wORDs: Adipose tissue, gestational diabetes mellitus, intrauterine environment, leptin, tumor necrosis factor- $\alpha$.

T umor necrosis factor (TNF)- $\alpha$ is a proinflammatory cytokine that may be important in the development of the metabolic syndrome. TNF- $\alpha$ expression in adipose tissue (AT) is elevated in obese individuals ${ }^{1}$ and correlates with adipocyte size. ${ }^{2}$ Robust AT expansion through adipocyte hypertrophy results in localized adipocyte death, and macrophages - the main source of TNF- $\alpha$ in $\mathrm{AT}^{3}$ - are recruited to remove necrotic adipocytes. ${ }^{4}$ Correlation studies suggest that TNF- $\alpha$ overabundance may lead to hepatic and/or peripheral insulin resistance, ${ }^{5,6}$ although this is not a consistent finding. ${ }^{7}$ Several mechanisms have been uncovered to explain why TNF- $\alpha$ overexpression engenders insulin resistance: directly, through impaired insulin signaling in target cells, ${ }^{8-10}$ and indirectly, through its actions on AT. Indeed, TNF- $\alpha$ inhibits preadi-

From the Department of Obstetrics and Gynecology, Katholieke Universiteit Leuven, Leuven, Belgium.

S.L. and this project were supported by grants from the Fonds voor Wetenschappelijk Onderzoek-Vlaanderen (Belgium), grant no. G.0221.03, and the Katholieke Universiteit Leuven, grant no. OT/02/48.

The authors thank E. Van Herck and L.Vercruysse for their help.

Address correspondence and reprint requests to: Suzan Lambin, Experimental Obstetrics and Gynecology, Onderwijs en Navorsing, Campus Gasthuisberg box 611, Herestraat 49, 3000 Leuven, Belgium. E-mail: suzan.lambin@med.kuleuven.be

Copyright (C) 2006 by the Society for Gynecologic Investigation. Published by Elsevier Inc. pocyte differentiation via down-regulation of peroxisome proliferator-activated receptor (PPAR) $\gamma$ (a pivotal transcriptional regulator of adipocyte differentiation) ${ }^{11}$ stimulates adipocyte apoptosis ${ }^{12}$ and raises circulating glycerol and free fatty acids (FFA) via increased lipolysis, ${ }^{13}$ a phenomenon thought to play a major role in the pathogenesis of type 2 diabetes. ${ }^{14}$ TNF- $\alpha$ also modulates the expression pattern of adipokines, with enhanced expression of leptin and apelin ${ }^{15,16}$ but blunted expression of adiponectin and resistin ${ }^{17,18}$; again, dysfunctional adipokine secretion has been linked to insulin resistance. ${ }^{14}$

Another matter of controversy is whether TNF- $\alpha$ acts locally, through a paracrine mode of action, or whether it has additional systemic effects (ie, an "endocrine" action). In mice with exclusive expression of TNF- $\alpha$ in AT, insulin resistance ensues solely at the AT level ${ }^{19}$; on the other hand, TNF- $\alpha$ infusion produces hepatic and peripheral insulin resistance in humans $^{20}$ and in rats. ${ }^{17,21}$

The metabolic syndrome encompasses glucose intolerance during pregnancy. The rise in TNF- $\alpha$ during normal pregnancy correlates with the decline in insulin sensitivity which may provoke glucose intolerance. ${ }^{22}$ In addition, serum TNF- $\alpha$ 
is increased in women with gestational diabetes mellitus (GDM) and in gravidas with an abnormal glucose challenge test when compared to body mass index-matched controls. ${ }^{23-26}$ During pregnancy, the placenta is a significant source of TNF- $\alpha,{ }^{27}$ and TNF- $\alpha$ receptor expression is upregulated in GDM placentas. ${ }^{24}$

In Pima Indians, the maternal 2-hour glucose level after a glucose load is related to the adiposity of their children, ${ }^{28}$ which may-at least in part-have its origin in the dysmetabolic and proinflammatory in utero environment. In an experiment in rats, TNF- $\alpha$ administration during gestation resulted in a sex-specific increase in body weight, adiposity, and fasting insulin in the offspring. ${ }^{29}$ Since the rat placenta is impermeable to TNF- $\alpha,{ }^{30}$ these effects would need to be initiated in utero through the actions of TNF- $\alpha$ on maternal metabolism. To confirm or refute this hypothesis, we examined the effects of TNF- $\alpha$ in C57BL6/J mice, which are susceptible to glucose intolerance at an early age. ${ }^{31}$ We sought to answer the following questions: (1) Does TNF- $\alpha$ infusion in the second part of pregnancy lead to glucose intolerance?; (2) Does TNF- $\alpha$ infusion raise maternal serum levels of leptin, FFA, and glycerol, and does it have an effect on adipocyte number and size?; and (3) Does TNF- $\alpha$ infusion accelerate growth and AT accumulation in the offspring of these mice? The offspring were followed until the postpubertal age of 8 weeks. In the females, we measured AT mRNA levels of TNF- $\alpha$, PPAR $\gamma 2$ (the PPAR $\gamma$-isoform expressed almost exclusively in AT), and several other adipokines (leptin, resistin, apelin); in the males, we assessed fat mass using dual-energy $\mathrm{x}$-ray absorptiometry (DXA), adipocyte size, and insulin sensitivity by the insulin tolerance test.

\section{ANIMALS AND METHODS}

The study protocol was approved by the local ethical committee for animal research. Female and male 8-week-old C57BL6/J mice (abbreviated hereafter as B6 mice) were purchased from the Jackson Laboratory (Bar Harbor, ME). The mice were housed in a temperature-, humidity-, and lightcontrolled environment and had ad libitum access to tap water and a standard laboratory chow containing $51 \%$ carbohydrate, $3 \%$ fat, and 21\% protein (Trouw, Gent, Belgium). The mice were mated overnight; the presence of a vaginal copulatory plug was defined as day (d) 0.5 of gestation. Alzet osmotic minipumps (Model 2001, Alzet, Palo Alto, CA) were implanted subcutaneously in the dorsal midline of the animals on d11.5 of gestation under light ether anesthesia. The pumps released either saline or recombinant mouse (rm)TNF- $\alpha$ (Leinco Technologies Inc, St. Louis, MO) for 7 days.

\section{Experiment 1: Dose-Finding Study}

We studied three groups of mice: saline-infusion and infusion of either $2 \mu \mathrm{g}$ or $4 \mu \mathrm{g}$ rmTNF- $\alpha$ over a period of 7 days, which corresponds to $75 \mu \mathrm{g} / \mathrm{kg}\left(0.45 \mu \mathrm{g} \cdot \mathrm{kg}^{-1} \cdot \mathrm{h}^{-1}\right)$ and $150 \mu \mathrm{g} / \mathrm{kg}\left(0.89 \mu \mathrm{g} \cdot \mathrm{kg}^{-1} \cdot \mathrm{h}^{-1}\right)$, respectively. These doses were chosen, because Ruan et al found insulin resistance in rats after infusing TNF- $\alpha$ at approximately $1.0 \mu \mathrm{g} \cdot \mathrm{kg}^{-1} \cdot \mathrm{h}^{-1}$ for
96 hours. ${ }^{17}$ The study end points were maternal glucose tolerance on d18.5 of gestation and reproductive outcome. Glucose tolerance tests (GTTs) were performed after an overnight fast. We injected $2 \mathrm{~g}$ glucose $/ \mathrm{kg}$ intraperitoneally (IP), and obtained blood samples by tail-snipping for glucose measurement before and 20, 30, 60, 90, and 120 minutes after glucose administration. Before and 20 and 90 minutes after glucose loading, blood samples were also collected into heparinized tubes, centrifuged and stored at $-20 \mathrm{C}$ for later plasma insulin measurement. Glucose was measured using a Glucocard Memory 2 glucometer (Menarini, Florence, Italy) and insulin by a mouse-specific enzyme-linked immunoassay (Mercodia, Uppsala, Sweden). Following the GTT, a cesarean section was performed under anesthesia (ketamine $80 \mathrm{mg} / \mathrm{kg}$ and xylazine $5 \mathrm{mg} / \mathrm{kg}$, both IP), and fetuses and placentas were weighed.

\section{Experiment 2: Effects of TNF- $\alpha$ ( $2 \mu \mathrm{g}$ over 7 days) on Maternal AT Characteristics}

Since the $2-\mu \mathrm{g}$ but not the $4-\mu \mathrm{g}$ dose was accompanied by reduced glucose tolerance (see Results), we used the former dose in further experiments in a separate set of mice. On d18.5 of gestation, we collected blood by tail-snipping after a 5-hour fast for determination of serum glycerol and FFA. Thereafter, we anesthetized the animals and collected a larger blood sample from the abdominal aorta, which was allowed to clot, centrifuged and stored for measurement of leptin and TNF- $\alpha$. Perigonadal white adipose tissue (WAT), subcutaneous inguinal WAT, and interscapular brown adipose tissue (BAT) were carefully dissected and weighed. WAT samples were used to determine AT cellularity and adipocyte area (size). For the former, adipocytes were isolated from 50 to $100 \mathrm{mg}$ perigonadal WAT by a slightly modified version of Rodbell's method, ${ }^{32}$ with all procedures at $37 \mathrm{C}$. WAT was washed in saline, cut into small pieces and transferred to a vial with $3 \mathrm{~mL}$ Krebs-Ringer bicarbonate (KRBA) buffer with $2 \%$ bovine serum albumin (BSA), $3 \mathrm{mM}$ glucose ( $\mathrm{pH} 7.4$ ), and $1 \mathrm{mg} / \mathrm{mL}$ collagenase. The vial was incubated for 1 hour in a shaking water bath, manually shaken to liberate adipocytes, centrifuged (1 minute at $400 \mathrm{~g}$ ), and the top layer washed with $5 \mathrm{~mL} \mathrm{KRBA}$; this procedure was repeated twice. The adipocytes were resuspended in $1 \mathrm{~mL} \mathrm{KRBA}$, stained with trypan blue, and counted in a Fuchs-Rosenthal chamber. The adipocyte area was assessed in perigonadal and inguinal WAT fixated in Bouin's solution and embedded in paraffin; $3 \mu \mathrm{m}$-thick sections were stained with hematoxylin-eosin. The area of all adipocytes was measured by computer-assisted image analysis (KS400, Zeiss, Zaventem, Belgium) in $7.11 \pm 0.06$ fields (mean \pm SEM) per mice, corresponding to $1205 \pm 99$ assessed adipocytes.

The level of FFA was determined using the NEFA C enzyme assay (Wako, Neuss, Germany) adapted to 96-well microtiter plates, ${ }^{33}$ and glycerol with the Free Glycerol Determination Kit (Sigma) adapted for $5 \mu \mathrm{L}$ serum with $300 \mu \mathrm{L}$ free glycerol reagent. Serum TNF- $\alpha$ was quantified using the mouse-specific TNF- $\alpha$ TiterZyme enzyme immunoassay from 
Table 1. Litter Size, Fetal and Placenta Weight, and Fetal/Placenta Weight Ratio in B6 Mice Infused With Saline, TNF- $\alpha 2 \mu \mathrm{g}$, or TNF- $\alpha 4 \mu \mathrm{g}$ from Day 11.5 to 18.5 of Gestation

\begin{tabular}{lcrr}
\hline & Saline & TNF- $\boldsymbol{\alpha} \mathbf{2} \boldsymbol{\mu g}$ & TNF- $\boldsymbol{\alpha} \mathbf{4} \boldsymbol{\mu g}$ \\
\hline Maternal weight d18.5 $(\mathrm{g})$ & $38.4 \pm 1.3(n=6)$ & $37.7 \pm 1.3(n=7)$ & $37.4 \pm 1.0(n=6)$ \\
Litter size & $7.5 \pm 0.5(n=6)$ & $6.7 \pm 0.9(n=7)$ & $7.2 \pm 1.1(n=6)$ \\
Fetal weight $(\mathrm{g})$ & $1.015 \pm 0.011(n=43)$ & $1.073 \pm 0.017(n=44)^{\dagger}$ & $0.967 \pm 0.015(n=38)^{\ddagger}$ \\
Placenta (g) & $0.098 \pm 0.002(n=43)$ & $0.099 \pm 0.002(n=44)$ & $0.091 \pm 0.001(n=39)^{\ddagger}$ \\
Fetal/placenta weight & $10.3 \pm 0.2(n=44)$ & $11.0 \pm 0.3(n=44)^{*}$ & $10.5 \pm 0.2(n=36)$ \\
\hline
\end{tabular}

Data are means \pm SEM (number of observations in parentheses).

$* P<.05$.

${ }^{\dagger} P<.01$, TNF- $\alpha 2 \mu \mathrm{g}$ vs saline.

$¥ P<.01$, TNF- $\alpha 4 \mu \mathrm{g}$ vs saline, as determined by two-sample $t$ test.

Assay Designs (Ann Arbor, MI), and leptin by a mouse-specific radioimmunoassay (Linco, St. Charles, MO).

\section{Experiment 3: Effects of TNF- $\alpha(2 \mu \mathrm{g}$ over 7 days) on AT Development in the Offspring}

The dams were allowed to deliver and the pups were weaned at 4 weeks of age. The body weight (BW) of all pups was recorded to the nearest $0.01 \mathrm{~g}$ weekly from $\mathrm{d} 7$ to $\mathrm{d} 56$. On $\mathrm{d} 56$, insulin tolerance tests were performed in fed male mice: blood samples were obtained by tail-snipping before and 15, 30, 45, and 60 minutes after insulin administration (Humulin Regular, Eli Lilly, Brussels, Belgium; $1 \mathrm{U} / \mathrm{kg}$ IP) and blood glucose was measured as indicated above. These animals were anesthetized on d57 for DXA using a densitometer for small animals (Piximus 2, Lunar, Madison, WI); the specimen heads were excluded from the analyses.

In both female and male mice, tail blood samples were obtained after an overnight fast on $\mathrm{d} 56$ or $\mathrm{d} 57$, respectively; the serum was stored for measurement of FFA, insulin, leptin, and $\mathrm{TNF}-\alpha$, as described. After euthanizing the mice by spinal cord elongation, intra-abdominal (perigonadal, mesenteric, and perirenal) and inguinal WAT and BAT were dissected. Tissue samples were snap-frozen in liquid nitrogen (polymerase chain reaction $[\mathrm{PCR}]$ ) in the females or immersed in Bouin's solution (histology) in the males. The adipocyte area was assessed as described above, in seven fields per mice, corresponding to $2620 \pm 161$ adipocytes.

For quantitative real-time PCR (RT-PCR), total RNA was extracted from 50 to $100 \mathrm{mg}$ homogenized WAT (perigonadal, mesenteric, and inguinal) and BAT using Tripure Reagent (Roche, Mannheim, Germany) according to the manufacturer's instructions; the RNA concentration was determined spectrophotometrically and stored at $-80 \mathrm{C}$. Reverse transcription reactions were performed from $100 \mathrm{ng}$ RNA using Taqman Reverse Transcription Reagents (Applied Biosystems, Lennik, Belgium). Oligonucleotide primers and probes were obtained for 5 mRNA species: PPAR $\gamma 2$, leptin, resistin, apelin, and TNF- $\alpha$. Primers and probe sets for PPAR $\gamma 2$ were obtained from Applied Biosystems (assay-by-design): sense primer 5'-CGCTGATGCACTGCCTATGA-3', antisense primer 5' AATGGCATCTCTGTGTCAACCA-3', probe 5'-(FAM)CACTTCACAAGAAATTAC-3' . For leptin, resistin, apelin, and $T N F-\alpha$, predesigned Taqman Gene Expression assays were purchased (leptin: Mm00434759_m1; resistin: Mm00445641_m1; apelin: Mm00443562_m1; TNF- $\alpha$ : Mm00443258_m1). 18s rRNA was used as the housekeeping gene and primers and Vic-Tamra probe were obtained as a Pre-Developed Assay Reagent (Applied Biosystems). Quantitative RT-PCR was performed using the ABI 7000 sequence detector after performing a validation experiment for each gene. PCR amplifications were performed in duplicate wells using 1:8 sample dilutions of cDNA and $2 \times$ TaqMan Universal PCR Master Mix. Thermal cycling conditions were 95C for 15 seconds and $60 \mathrm{C}$ for 1 minute (40 cycles). The data were obtained as $\mathrm{Ct}$ values (the cycle number at which PCR target plots crosses the arbitrary threshold) and normalized to the expression levels of $18 \mathrm{~s}$ rRNA $(\Delta \mathrm{Ct}=\mathrm{Ct}$ target gene $-\mathrm{Ct}$ 18s rRNA). To compare differences between groups results

\section{GLUCOSE}

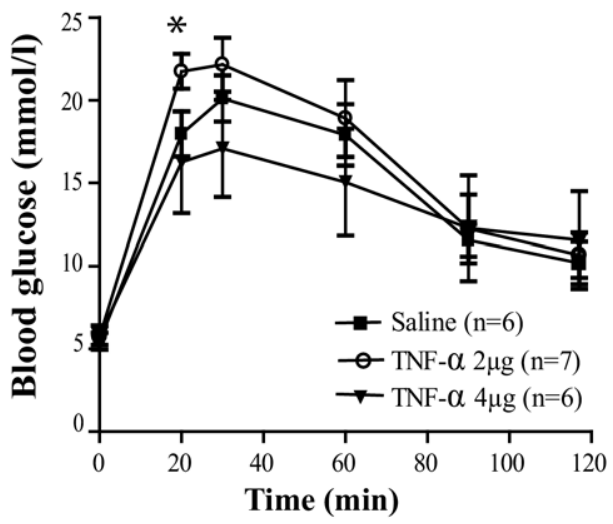

INSULIN

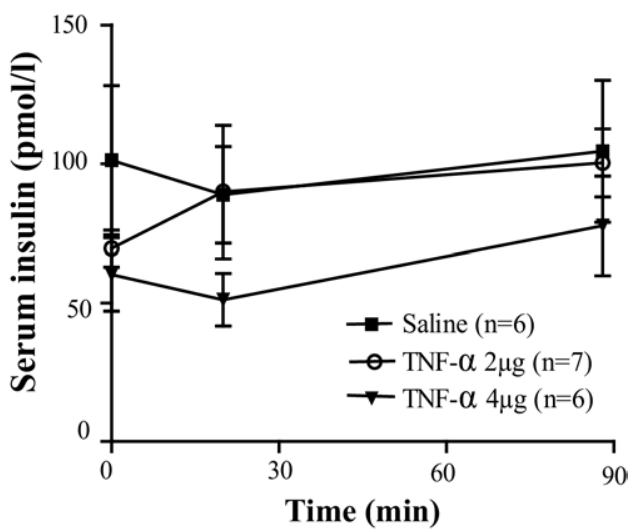

Figure 1. Glucose tolerance test in d18.5 gravid B6 mice infused with saline, TNF- $\alpha 2 \mu \mathrm{g}$ or TNF- $\alpha 4 \mu \mathrm{g}$ from $\mathrm{d} 11.5$ to $\mathrm{d} 18.5$. Blood glucose concentrations (left) and serum insulin concentrations (right) after an IP glucose load $(2 \mathrm{~g} / \mathrm{kg})$. Statistical analysis was performed by two-sample $t$ test. The data are shown as means \pm SEM; *significantly different $(P<.05)$ from the respective value of the saline-infused group. 
Table 2. Fasting Serum Concentrations of FFA, Glycerol, and Leptin; Weight of Fat Pads; and Adipocyte Area and Number, in Day 18.5 Gravid B6 Mice Infused With Saline or TNF- $\alpha 2 \mu \mathrm{g}$ from Day 11.5 to 18.5

\begin{tabular}{lccc}
\hline & Saline & TNF- $\alpha \mathbf{2} \boldsymbol{\mu g}$ & $\boldsymbol{P}$ value \\
\hline Serum & & & \\
$\quad$ FFA $(\mu \mathrm{Eq} / \mathrm{L})$ & $1440 \pm 178(7)$ & $1103 \pm 136(7)$ & .16 \\
$\quad$ Glycerol $(\mathrm{mmol} / \mathrm{L})$ & $5.08 \pm 0.51(7)$ & $6.38 \pm 0.71(7)$ & .16 \\
$\quad$ Leptin $(\mathrm{nmol} / \mathrm{L})$ & $0.42 \pm 0.01(6)$ & $0.42 \pm 0.04(7)$ & .92 \\
AT weight $(\mathrm{mg})$ & & & \\
$\quad$ Perigonadal & $212 \pm 22(7)$ & $252 \pm 26(7)$ & .26 \\
$\quad$ Inguinal & $212 \pm 22(7)$ & $212 \pm 20(7)$ & .99 \\
$\quad$ Brown & $52 \pm 6(7)$ & $53 \pm 5(7)$ & .85 \\
Adipocyte number & & & \\
$\quad\left(\times 10^{6}\right)$ & & & .87 \\
$\quad$ Perigonadal & $48.4 \pm 5.7(7)$ & $49.7 \pm 4.4(7)$ & \\
Adipocyte area $\left(\mu \mathrm{m}^{2}\right)$ & & & \\
$\quad$ Perigonadal & $694 \pm 65(6)$ & $925 \pm 144(7)$ & .20 \\
$\quad$ Inguinal & $666 \pm 232(7)$ & $859 \pm 113(7)$ & .47 \\
\hline
\end{tabular}

Data are means \pm SEM (number of observations between brackets).

$P<.05$, TNF- $\alpha 2 \mu \mathrm{g}$ vs saline, as determined by two-sample $t$ test.

were expressed as relative expression $(\Delta \Delta \mathrm{Ct}=\Delta \mathrm{Ct}$ TNF- $\alpha$ group $-\Delta \mathrm{Ct}$ control group), and presented as $2^{-\Delta \Delta \mathrm{Ct}}$ ( \pm SEM) with the resultant numerical values expressing the $n$-fold of increase or decrease of the target mRNA with respect to the calibrator and the SEM calculated as follows: SEM = $\left[2^{-\Delta \Delta \mathrm{Ct}} \cdot \ln 2 \cdot \mathrm{SD} \quad(-\Delta \Delta \mathrm{Ct})\right] /($ number of samples per group) $)^{1 / 2}$.

\section{Data Analysis}

Data analysis was performed with the NCSS 2004 software (Kaysville, UT). We used two-sample $t$ tests (comparison of data from the two groups), and one-way and GLM analysis of variance (ANOVA), followed (if $P<.05$ ) by Fisher least significant difference (LSD) multiple comparison test to detect intergroup differences. All data are presented as means \pm SEM. Statistical significance was set at $P<.05$.
Table 3. Weight of Fat Pads; Serum Concentrations of FFA, Insulin and Leptin; and Blood Glucose Levels in the Female Offspring (d56) of B6 Mice Infused With Saline or TNF- $\alpha 2 \mu \mathrm{g}$ During Gestation (d11.5-18.5)

\begin{tabular}{|c|c|c|c|}
\hline & Saline & TNF- $\alpha 2 \mu \mathrm{g}$ & $P$ value \\
\hline \multicolumn{4}{|l|}{ AT Weight (mg) } \\
\hline Perigonadal & $84.5 \pm 6.5(19)$ & $119.1 \pm 7.2(9)^{\dagger}$ & .003 \\
\hline Mesenteric & $29.0 \pm 2.4(19)$ & $32.5 \pm 3.5(9)$ & .42 \\
\hline Perirenal & $10.3 \pm 0.9(19)$ & $17.3 \pm 0.3(9)^{\dagger}$ & .008 \\
\hline Inguinal & $46.4 \pm 3.6(17)$ & $59.3 \pm 3.0(9)^{*}$ & .026 \\
\hline Brown & $57.8 \pm 1.6(19)$ & $63.4 \pm 2.1(9)^{*}$ & .046 \\
\hline \multicolumn{4}{|l|}{ Fat percentage $(\%)$} \\
\hline$\Sigma \mathrm{AT} / \mathrm{BW}$ & $1.38 \pm 0.06(19)$ & $1.63 \pm 0.10(9)^{*}$ & .026 \\
\hline \multicolumn{4}{|l|}{ Blood } \\
\hline Glucose $(\mathrm{mmol} / \mathrm{L})$ & $3.82 \pm 0.12(19)$ & $4.29 \pm 0.06(8)^{*}$ & .021 \\
\hline \multicolumn{4}{|l|}{ Serum } \\
\hline FFA $(\mu \mathrm{Eq} / \mathrm{L})$ & $1819 \pm 151(12)$ & $1633 \pm 116(10)$ & .36 \\
\hline Insulin $(\mathrm{pmol} / \mathrm{L})$ & $32 \pm 9(11)$ & $19 \pm 5(10)$ & .23 \\
\hline Leptin (pmol/L) & $8.6 \pm 3.7(6)$ & $20.1 \pm 8.9(6)$ & .26 \\
\hline
\end{tabular}

\section{RESULTS}

\section{Experiment 1}

Saline- and TNF- $\alpha$-infused mice had comparable BWs on $\mathrm{d} 0.5(22.2 \pm 0.3 \mathrm{~g}$ for saline, $22.1 \pm 0.6 \mathrm{~g}$ for TNF- $\alpha 2 \mu \mathrm{g}$, and $21.4 \pm 0.4 \mathrm{~g}$ for TNF- $\alpha 4 \mu \mathrm{g} ; P=.85$ by ANOVA), as well as on d18.5 (Table 1) of gestation. While litter size was also comparable, fetal and placental weights were affected by TNF- $\alpha$ infusion: the $2-\mu \mathrm{g}$ TNF- $\alpha$ infusion increased fetal but not placental weight, whereas the $4-\mu \mathrm{g}$ dose reduced both fetal and placental weight.

Dams receiving $2 \mu \mathrm{g}$ TNF- $\alpha$ had an increased glucose excursion after the IP glucose load compared to dams receiving saline (Figure 1); however, the insulin output during the GTT was comparable. No significant difference in glucose concen-
Figure 2. Body weight from d7 until $\mathrm{d} 56 / 57$ in female (left) and male (right) offspring of B6 mice infused with saline or TNF- $\alpha 2 \mu \mathrm{g}$ during gestation (d11.5-18.5). Statistical analysis (for BW at each time point) was performed by two-sample $t$ test. The data shown are shown as means $\pm \mathrm{SEM} ;{ }^{*}(P<.05)$ and $* *(P<.01)$ significantly different from the respective value of the salineinfused group.

\section{FEMALE OFFSPRING}

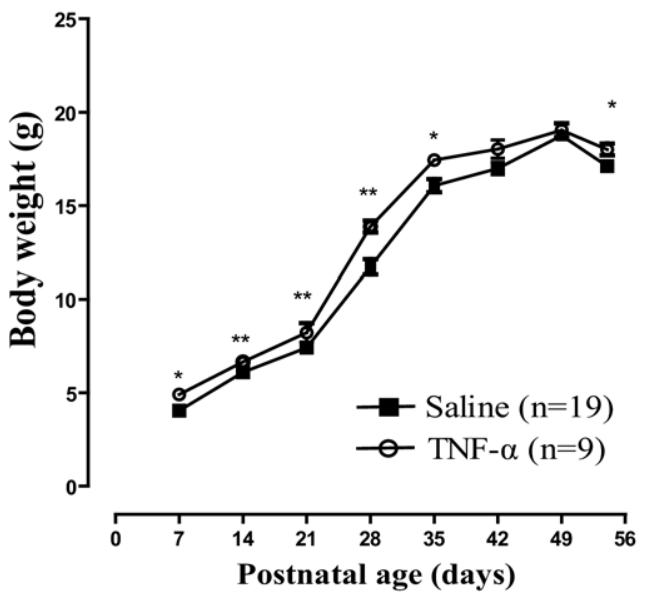

MALE OFFSPRING

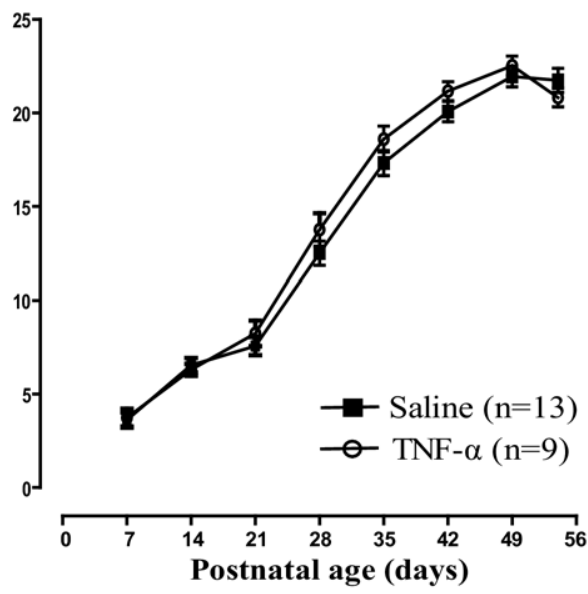




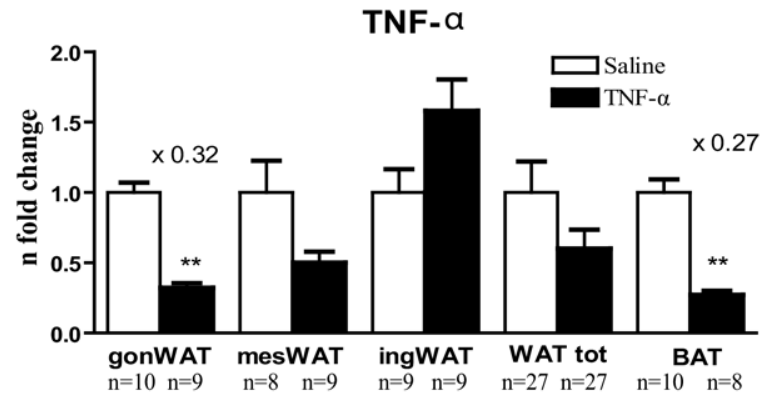

PPAR $Y 2$

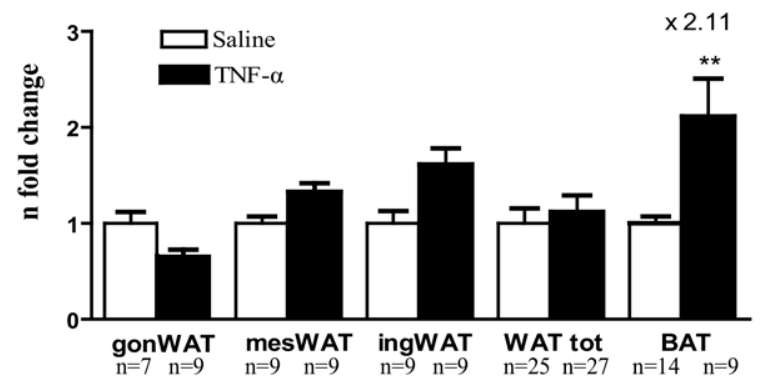

Leptin

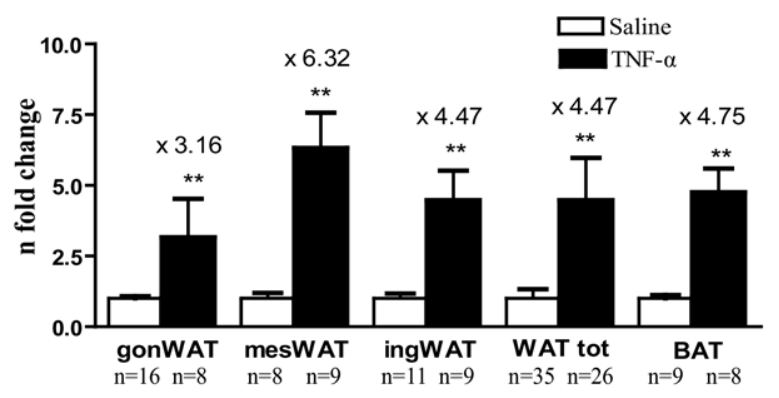

Resistin

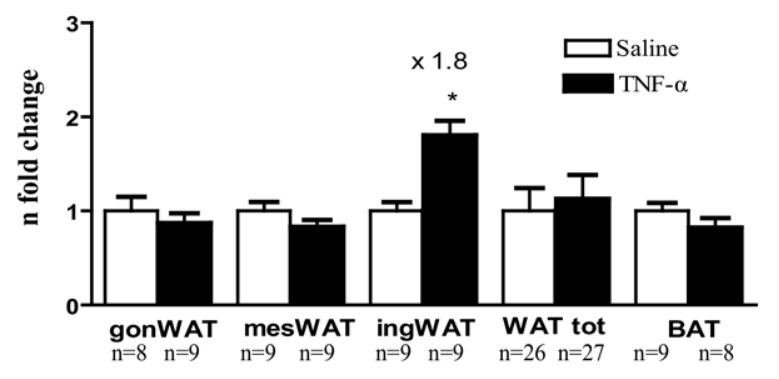

Apelin

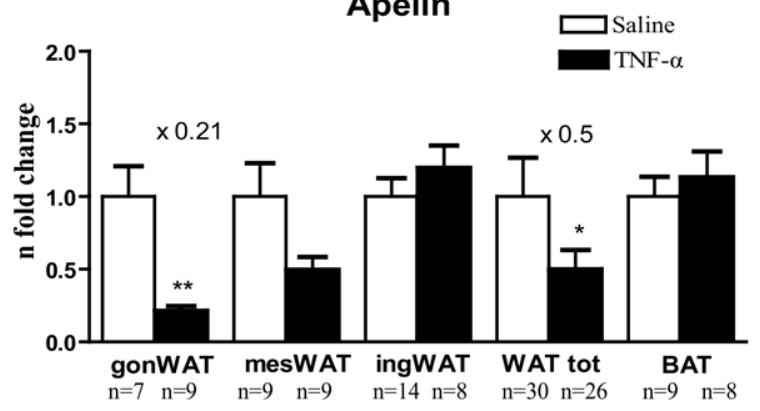

Figure 3. Adipokine gene expression in AT of female offspring (d56) of B6 mice infused with saline or TNF- $\alpha 2 \mu \mathrm{g}$ during gestation (d11.5-18.5). TNF- $\alpha$, PPAR $\gamma 2$, leptin, resistin, and apelin mRNA trations was observed between dams receiving $4 \mu \mathrm{g}$ TNF- $\alpha$ and the saline group, but insulin concentrations tended to be lower in the TNF- $\alpha$ group $(P=.098)$.

\section{Experiment 2}

On the basis of experiment 1 , the effects of the $2-\mu \mathrm{g}$ dose on AT were examined. We found no differences in serum FFA and glycerol concentrations in dams infused with $2 \mu \mathrm{g}$ TNF- $\alpha$, nor in AT weight, adipocyte number, or adipocyte area (Table 2). Serum TNF- $\alpha$ was undetectable $(<20.1 \mathrm{pg} / \mathrm{mL})$ in all analyzed sera.

\section{Experiment 3}

Figure 2 shows the BW curves between $\mathrm{d} 7$ and $\mathrm{d} 56$. Throughout this period, females exposed to TNF- $\alpha$ ( $2 \mu \mathrm{g}$ dose) in utero were heavier than the female offspring of saline-infused mothers. In the male offspring, this difference was attenuated and not significant $(.13<P<.93$ at the various ages). Female offspring exposed to TNF- $\alpha$ in utero also had more perigonadal, perirenal and inguinal WAT, as well as more BAT, than females exposed to saline (Table 3); however, the weight of the liver was not different $(P=.61)$. Blood glucose levels were also higher, but there was no difference in the serum concentrations of FFA, insulin, and leptin. In line with the growth data, the male offspring exposed to TNF- $\alpha$ in utero did not show higher adiposity $(.32<P<.90$ for the various AT depots). In addition, we found no differences in fat mass $(P=.93)$ or fat percentage $(P=.74)$ as derived from the DXA measurements, nor in the adipocyte area (perigonadal WAT: $P=.60$; inguinal WAT: $P=.13)$. Blood glucose $(P=.63)$, serum FFA $(P=.34)$, and insulin $(P=.67)$ were not different either, but serum leptin values tended to be increased in the male TNF- $\alpha$ group $(33.5 \pm 11.0$ vs $7.9 \pm 4.8 \mathrm{pmol} / \mathrm{L}$ in the saline group; $P=.059)$. Serum TNF- $\alpha$ was undetectable in 21 of 35 sera analyzed, with no difference between the saline and TNF- $\alpha$-exposed offspring.

The insulin tolerance tests were not different between TNF- $\alpha-$ and saline-exposed male offspring: there was no difference in blood glucose at any of the time points $(.13<P<.39)$; and the area under the glucose curve was also comparable $(P=.17)$.

We found a robust increase (between 216\% and 532\%) in leptin gene expression in all WAT depots, as well as in BAT of female offspring exposed to TNF- $\alpha$ in utero (Figure 3); in addition, resistin expression was increased by $80 \%$ in inguinal WAT. In contrast, TNF- $\alpha$ mRNA levels were normal or decreased in the TNF- $\alpha$ offspring, with a significant differ-

levels were assessed by quantitative RT-PCR in gonWAT (perigonadal WAT), mesWAT (mesenteric), ingWAT (inguinal), WAT tot $($ gonWAT + mesWAT + ingWAT), and BAT (brown AT). The data were transformed from $\mathrm{Ct}$ values to equivalent $n$-fold differences, with the expression level of the saline-infused group set at 1.0. Intergroup differences were assessed using two-sample $t$ tests. ${ }^{*} P<.05,{ }^{*} P<.01$, TNF- $\alpha 2 \mu \mathrm{g}$ compared to saline, with the $n$-fold difference compared to the saline group on top of the bar. 
ence in perigonadal WAT and BAT; apelin mRNA was 79\% lower in perigonadal WAT as well. PPAR $\gamma 2$ mRNA levels were increased in BAT of TNF- $\alpha$-exposed offspring, but there was no difference in any of the WAT depots.

\section{DISCUSSION}

The first conclusion of this study is that a subcutaneous infusion of $2 \mu \mathrm{g}$ rmTNF- $\alpha$ in gravid B6 mice (from d11.5 tot d18.5) resulted in a mild GDM syndrome characterized by reduced glucose tolerance (higher peak value) and relative fetal macrosomia. However, there was no effect on FFA concentrations, or any other AT effects. The second conclusion is that the female but not male offspring of TNF- $\alpha$-infused mice showed increased weight gain owing - at least in part-to more pronounced AT accumulation. The females also showed higher leptin mRNA levels in all AT depots, as well as higher fasting blood glucose levels. Overall, the results suggest that TNF- $\alpha$ mediates some of the effects of GDM on fetal growth and postnatal hyperadiposity.

TNF- $\alpha$ administration affects both insulin sensitivity and secretion. In rats, a 4-day $\mathrm{TNF}-\alpha$ infusion reduced insulin sensitivity ${ }^{17}$; in addition, neutralization of TNF- $\alpha$ or its receptor by infusion of specific antibodies for 3 to 7 days improved insulin sensitivity, yet only in older or obese rats and at the level of the skeletal muscles and liver but not AT. ${ }^{1,34,35}$ TNF- $\alpha$-induced insulin resistance is the consequence of $a b-$ normal insulin signaling in various target cells (eg, hepatocytes, adipocytes, and myocytes), ${ }^{8-10}$ and, indirectly, through increased lipolysis. However, lipolysis by $\mathrm{TNF}-\alpha$ in vitro was shown to be activated only under hyperglycemic conditions. ${ }^{13}$ We found no change in fasting FFA and glycerol levels, in contrast to results obtained in rats ${ }^{17}$; this may be related to the slightly lower dose of TNF- $\alpha$ used in the current study $(0.45$ $\mu \mathrm{g} \cdot \mathrm{kg}^{-1} \cdot \mathrm{h}^{-1}$; cumulative dose: $2 \mu \mathrm{g}$ or $75 \mu \mathrm{g} / \mathrm{kg}$ ), whereas Ruan et al used approximately $1.0 \mu \mathrm{g} \cdot \mathrm{kg}^{-1} \cdot \mathrm{h}^{-1}$ (cumulative dose: $96 \mu \mathrm{g} / \mathrm{kg}$ ), or to a species-related difference. Regarding insulin secretion, $\mathrm{TNF}-\alpha$ was reported to inhibit glucosestimulated insulin secretion and to induce $\beta$-cell apoptosis in vitro. ${ }^{36}$ Such an inhibitory effect may explain why the $2-\mu \mathrm{g}$ TNF- $\alpha$ infusion did not result in the expected hyperinsulinemic curve after IP glucose loading, and why the 4- $\mu \mathrm{g}$ dose tended $(P<.10)$ to reduce glucose-stimulated insulin output (Figure 1). Interestingly, fasting $\mathrm{TNF}-\alpha$ was inversely correlated with insulin secretion indices during an intravenous GTT in gravidas with and without GDM in the third trimester. ${ }^{26}$ Of note, GDM is also characterized by both insulin resistance and a reduced insulin secretory response to glucose. ${ }^{37}$

The 4- $\mu \mathrm{g}$ TNF- $\alpha$ infusion $(150 \mu \mathrm{g} / \mathrm{kg})$ did not result in a further worsening of glucose intolerance compared with the $2-\mu \mathrm{g}$ infusion. However, we found a $9.4 \%$ lower fetal mass and a $12.2 \%$ lower placental mass per dam with the $4-\mu \mathrm{g}$ dose compared with saline (Table 1). These findings are in line with data in rats showing that TNF- $\alpha$ at high doses (100 or $500 \mu \mathrm{g} / \mathrm{kg}$, injected on d12) resulted in decidual and placental necrosis with increased fetal demise. ${ }^{38}$ The reduced fetoplacental mass likely produced a smaller degree of gestational insulin resistance; indeed, intrauterine growth restriction in humans has been linked to a "flat" oral GTT in their mothers. $^{39}$

TNF- $\alpha$ may have other effects on AT, including adipocyte apoptosis and inhibition of preadipocyte differentiation. ${ }^{11,12}$ However, a 7-day infusion in gravid B6 mice had no effect on adipocyte number or size, or on plasma leptin levels (Table 2). We were also unable to demonstrate elevated serum TNF- $\alpha$ levels after chronic TNF- $\alpha$ infusion. Serum concentrations of TNF- $\alpha$ are typically low in humans as well (mean, $<7 \mathrm{pg} / \mathrm{mL}$ in gravidas), ${ }^{23-26}$ in contrast to the mRNA abundance in AT and placenta. Nevertheless, our data support the hypothesis that TNF- $\alpha$ has an "endocrine" effect on glucose homeostasis.

Our offspring data (Figure 2 and Table 3) extend results reported in rats. ${ }^{29}$ Dahlgren et al administered approximately $1 \mu \mathrm{g}$ TNF- $\alpha$ IP on $\mathrm{d} 8, \mathrm{~d} 10$, and $\mathrm{d} 12$ of gestation. The litters were reassembled to include five or six females and four to six males, and were followed until 10 weeks (males) or 12 weeks (females) of age. The females weighed more between 4 and 8 weeks postnatal age than the controls, and had more perigonadal and perirenal WAT at 12 weeks; the males weighed more at 10 weeks of age, and had more perirenal WAT and higher fasting plasma insulin levels. Both Dahlgren's and our study showed a greater response to $\mathrm{TNF}-\alpha$ exposure in utero in female than in male offspring. Why such differences would occur is unclear at this time; however, serum TNF- $\alpha$ and the soluble TNF receptors were reported to be higher in both lean and obese women compared to their male counterparts. ${ }^{40}$ Male but not female mice lacking both endogenous leptin and TNF- $\alpha$ receptors showed reduced AT TNF- $\alpha$ mRNA, ${ }^{41}$ yet another example of a sex-specific effect regarding adipokine physiology. However, further mechanistic studies are mandatory.

We found a robust increase in leptin mRNA levels in all AT depots of TNF- $\alpha$-infused female offspring, as well as elevated resistin mRNA in inguinal WAT; in contrast, TNF- $\alpha$ mRNA was not increased and was even reduced in some of the AT depots, and apelin mRNA was lower in perigonadal WAT (Figure 3). It has been well documented that TNF- $\alpha$ stimulates leptin expression in WAT, ${ }^{15,42}$ but the leptin overexpression observed in TNF- $\alpha$ offspring likely reflects their hyperadiposity rather than a direct effect initiated in utero, since the placenta is impermeable to TNF- $\alpha .{ }^{30}$ It would be of complementary interest to assess the adipocyte area in female TNF- $\alpha$ offspring as well, since leptin mRNA levels in AT are closely correlated with adipocyte size. ${ }^{43}$ Like leptin, apelin expression is up-regulated in obese and hyperinsulinemic mice and in obese individuals ${ }^{44}$; in addition, apelin and TNF- $\alpha$ mRNA levels in AT from lean and obese subjects are correlated. ${ }^{16}$ Our results show discordant effects on leptin and apelin expression but concordant effects on TNF- $\alpha$ and apelin expression in AT of TNF- $\alpha$ offspring. While several studies in obese mouse models have documented reduced rather than augmented AT resistin mRNA levels, resistin expression paradoxically declines during fasting ${ }^{45}$; clearly, more work is needed on the regulation and significance of resistin. Finally, PPAR $\gamma 2$ expression was unaltered in all WAT depots, suggesting that the acceler- 
ated AT accumulation in the female TNF- $\alpha$ offspring was not explained by increased preadipocyte differentiation. ${ }^{11}$

Since there is no or minimal transfer of TNF- $\alpha$ across the placenta in rats ${ }^{30}$ or in humans, ${ }^{46,47}$ the offspring effects are likely the consequence of TNF- $\alpha$-induced metabolic changes during pregnancy. Although the maternal changes in glucose tolerance and lipid metabolism were mild after the 7-day infusion, earlier assessments might have captured more extensive adaptations; also, measuring glucose before the 20-minute time point might have enhanced the degree of glucose intolerance in the $2-\mu \mathrm{g}$ group. One should also keep in mind that in Pima Indians, higher maternal post-challenge glucose levels within the glucose-tolerant range were associated with increased adiposity in their offspring. ${ }^{28}$ Changes in other adipokines may also be important. For example, TNF- $\alpha$ stimulates interleukin-6 expression in an adipocyte cell line $e^{48}$; unlike TNF- $\alpha$, interleukin- 6 is transferred across the (human) placenta ${ }^{46}$ but, like TNF- $\alpha$, was found to affect growth and adiposity of the offspring in rats. ${ }^{29}$

The risk of obesity and glucose intolerance is increased in the progeny of women with GDM in US and European populations. ${ }^{28,49,50}$ Although the genetic constitution and the accrued likelihood of an obesigenic postnatal environment provide partial explanations for these observations, in utero metabolic programming may constitute a third contributing factor. The current study suggests that TNF- $\alpha$ may be a mediator of such in utero metabolic programming, and opens new avenues for further research.

\section{REFERENCES}

1. Hotamisligil GS, Shargill NS, Spiegelman BM. Adipose expression of tumor necrosis factor- $\alpha$ : Direct role in obesity-linked insulin resistance. Science 1993;259:87-91.

2. Winkler G, Kiss S, Keszthelyi L, et al. Expression of tumor necrosis factor (TNF)- $\alpha$ in the subcutaneous and visceral adipose tissue in correlation with adipocyte cell volume, serum TNF- $\alpha$, soluble serum TNF-receptor-2 concentrations and C-peptide level. Eur J Endocrinol 2003;149:129-35.

3. Weisberg SP, McCann D, Desai M, Rosenbaum M, Leibel RL, Ferrante AW. Obesity is associated with macrophage accumulation in adipose tissue. J Clin Invest 2003;112:1796-808.

4. Cinti S, Mitchell G, Barbatelli G, et al. Adipocyte death defines macrophage localization and function in adipose tissue of obese mice and humans. J Lipid Res 2005;46:2347-55.

5. Hotamisligil GS, Arner P, Caro JF, Atkinson RL, Spiegelman BM. Increased adipose tissue expression of tumor necrosis factor- $\alpha$ in human obesity and insulin resistance. J Clin Invest 1995;95:2409-15.

6. You T, Yang R, Lyles MF, Gong D, Nicklas BJ. Abdominal adipose tissue cytokine gene expression: Relationship to obesity and metabolic risk factors. Am J Physiol Endocrinol Metab 2005;288:E741-7.

7. Koistinen HA, Bastard JP, Dusserre E, et al. Subcutaneous adipose tissue expression of tumour necrosis factor- $\alpha$ is not associated with whole body insulin resistance in obese nondiabetic or in type-2 diabetic subjects. Eur J Clin Invest 2000;30:302-10.

8. Feinstein R, Kanety H, Papa MZ, Lunenfeld B, Karasik A. Tumor necrosis factor-alpha suppresses insulin-induced tyrosine phosphorylation of insulin receptor and its substrates. J Biol Chem 1993;268:26055-8.
9. Liu LS, Spelleken M, Rohrig K, Hauner H, Eckel J. Tumor necrosis factor-alpha acutely inhibits insulin signaling in human adipocytes: Implication of the p80 tumor necrosis factor receptor. Diabetes 1998;47:515-22.

10. del Aguila LF, Claffey KP, Kirwan JP. TNF- $\alpha$ impairs insulin signaling and insulin stimulation of glucose uptake in $\mathrm{C}_{2} \mathrm{C}_{12}$ muscle cells. Am J Physiol Endocrinol Metab 1999;276:E849-55.

11. MacDougald OA, Mandrup S. Adipogenesis: Forces that tip the scales. Trends Endocrinol Metab 2002;13:5-11.

12. Qian H, Hausman DB, Compton MM, et al. TNF- $\alpha$ induces and insulin inhibits caspase 3-dependent adipocyte apoptosis. Biochem Biophys Res Commun 2001;284:1176-83.

13. Green A, Rumberger JM, Stuart CA, Ruhoff MS. Stimulation of lipolysis by tumor necrosis factor- $\alpha$ in $3 \mathrm{~T} 3-\mathrm{L} 1$ adipocytes is glucose dependent: Implications for long-term regulation of lipolysis. Diabetes 2004;53:74-81.

14. Bays H, Mandarino L, DeFronzo RA. Role of the adipocyte, free fatty acids, and ectopic fat in pathogenesis of type 2 diabetes mellitus: Peroxisomal proliferator-activated receptor agonists provide a rational therapeutic approach. J Clin Endocrinol Metab 2004;89:463-78.

15. Finck BN, Johnson RW. Tumor necrosis factor (TNF)- $\alpha$ induces leptin production through the p55 TNF receptor. Am J Physiol Regul Integr Comp Physiol 2000;278:R537-43.

16. Daviaud D, Boucher J, Gesta S, et al. TNF $\alpha$ up-regulates apelin expression in human and mouse adipose tissue. FASEB J 2006;20:1528-30.

17. Ruan H, Miles PD, Ladd CM, et al. Profiling gene transcription in vivo reveals adipose tissue as an immediate target of tumor necrosis factor- $\alpha$ : Implications for insulin resistance. Diabetes 2002;51:3176-88.

18. Fasshauer M, Klein J, Neumann S, Eszlinger M, Paschke R. Tumor necrosis factor $\alpha$ is a negative regulator of resistin gene expression and secretion in 3T3-L1 adipocytes. Biochem Biophys Res Commun 2001;288:1027-31.

19. Xu H, Hirosumi J, Uysal KT, Guler AD, Hotamisligil GS. Exclusive action of transmembrane TNF $\alpha$ in adipose tissue leads to reduced adipose mass and local but not systemic insulin resistance. Endocrinology 2002;143:1502-11.

20. Plomgaard P, Bouzakri K, Krogh-Madsen R, Mittendorfer B, Zierath JR, Pedersen BK. Tumor necrosis factor- $\alpha$ induces skeletal muscle insulin resistance in healthy human subjects via inhibition of Akt substrate 160 phosphorylation. Diabetes 2005; 54:2939-45.

21. Lang CH, Dobrescu C, Bagby GJ. Tumor necrosis factor impairs insulin action on peripheral glucose disposal and hepatic glucose output. Endocrinology 1992;130:43-52.

22. Kirwan JP, Hauguel-De Mouzon S, Lepercq J, et al. TNF- $\alpha$ is a predictor of insulin resistance in human pregnancy. Diabetes 2002;51:2207-13.

23. Winkler G, Cseh K, Baranyi E, et al. Tumor necrosis factor system in insulin resistance in gestational diabetes. Diabetes Res Clin Pract 2002;56:93-9.

24. Radaelli T, Varastehpour A, Catalano P, Hauguel-de Mouzon S. Gestational diabetes induces placental genes for chronic stress and inflammatory pathways. Diabetes 2003;52:2951-8.

25. Verhaeghe J, van Bree R, Lambin S, Caluwaerts S. Adipokine profile and C-reactive protein in pregnancy: Effects of glucose challenge response versus body mass index. J Soc Gynecol Investig 2005;12:330-4.

26. McLachlan KA, O'Neal D, Jenkins A, Alford FP. Do adiponectin, TNF $\alpha$, leptin and CRP relate to insulin resistance in pregnancy? Studies in women with and without gestational diabetes, during and after pregnancy. Diabetes Metab Res Rev 2006;22: 131-8.

27. Chen HL, Yang YP, Hu XL, Yelavarthi KK, Fishback JL, Hunt JS. Tumor necrosis factor alpha mRNA and protein are present 
in human placental and uterine cells at early and late stages of gestation. Am J Pathol 1991;139:327-35.

28. Franks PW, Looker HC, Kobes S, et al. Gestational glucose tolerance and risk of type 2 diabetes in young Pima Indian offspring. Diabetes 2006;55:460-5.

29. Dahlgren J, Nilsson C, Jennische E, et al. Prenatal cytokine exposure results in obesity and gender-specific programming. Am J Physiol Endocrinol Metab 2001;281:E326-34.

30. Carbó N, López-Soriano FJ, Argilés JM. Tumour necrosis factor- $\alpha$ does not cross the rat placenta. Cancer Lett 1998; 128:101-4.

31. Goren HJ, Kulkarni RN, Kahn CR. Glucose homeostasis and tissue transcript content of insulin signaling intermediates in four inbred strains of mice: C57BL/6, C57BLKS/6, DBA/2, and 129X1. Endocrinology 2004;145:3307-23.

32. Rodbell M. Metabolism of isolated fat cells. I. Effects of hormones on glucose metabolism and lipolysis. J Biol Chem 1964;239:375-80.

33. Johnson MM, Peters JP. An improved method to quantify nonesterified fatty acids in bovine plasma. J Anim Sci 1993;71:753-6.

34. Cheung AT, Ree D, Kolls JK, Fuselier J, Coy DH, Bryer-Ash M. An in vivo model for elucidation of the mechanism of tumor necrosis factor- $\alpha(\mathrm{TNF}-\alpha)$-induced insulin resistance: Evidence for differential regulation of insulin signaling by TNF- $\alpha$. Endocrinology 1998;139:4928-35.

35. Borst SE, Lee Y, Conover CF, Shek EW, Bagby GJ. Neutralization of tumor necrosis factor- $\alpha$ reverses insulin resistance in skeletal muscle but not adipose tissue. Am J Physiol Endocrinol Metab 2004;287:E934-8.

36. Zhao YF, Feng DD, Chen C. Contribution of adipocyte-derived factors to beta-cell dysfunction in diabetes. Int J Biochem Cell Biol 2006;38:804-19.

37. Xiang AH, Peters RK, Trigo E, Kjos SL, Lee WP, Buchanan TA. Multiple metabolic defects during late pregnancy in women at high risk for type 2 diabetes. Diabetes 1999;48:848-54.

38. Silen ML, Firpo A, Morgello S, Lowry SF, Francus T. Interleukin- $1 \alpha$ and tumor necrosis factor $\alpha$ cause placental injury in the rat. Am J Pathol 1989;135:239-44.

39. Langer O, Damus K, Maiman M, Divon M, Levy J, Bauman W. A link between hypoglycemia-hypoinsulinemia during oral glu- cose tolerance tests and intrauterine growth retardation. Am J Obstet Gynecol 1986;155:711-6.

40. Corica F, Allegra A, Corsonello A, et al. Relationship between plasma leptin levels and the tumor necrosis factor- $\alpha$ system in obese subjects. Int J Obes 1999;23:355-60.

41. Neels JG, Pandey M, Hotamisligil GS, Samad F. Autoamplification of tumor necrosis factor- $\alpha$ : A potential mechanism for the maintenance of elevated tumor necrosis factor- $\alpha$ in male but not female obese mice. Am J Pathol 2006;168:435-44.

42. Kirchgessner TG, Uysal KT, Wiesbrock SM, Marino MW, Hotamisligil GS. Tumor necrosis factor- $\alpha$ contributes to obesityrelated hyperleptinemia by regulating leptin release from adipocytes. J Clin Invest 1997;100:2777-82.

43. Guo K-Y, Halo P, Leibel RL, Zhang Y. Effects of obesity on the relationship of leptin mRNA expression and adipocyte size in anatomically distinct fat depots in mice. Am J Physiol Regul Integr Comp Physiol 2004;287:R112-9.

44. Boucher J, Masri B, Daviaud D, et al. Apelin, a newly identified adipokine up-regulated by insulin and obesity. Endocrinology 2005; 146:1764-71

45. Rajala MW, Qi Y, Patel HR, et al. Regulation of resistin expression and circulating levels in obesity, diabetes, and fasting. Diabetes 2004;53:1671-9.

46. Zaretsky MV, Alexander JM, Byrd W, Bawdon RE. Transfer of inflammatory cytokines across the placenta. Obstet Gynecol 2004;103:546-50.

47. Aaltonen R, Heikkinen T, Hakala K, Laine K, Alanen A. Transfer of proinflammatory cytokines across term placenta. Obstet Gynecol 2005;106:802-7.

48. Ruan H, Hacohen N, Golub TR, Van Parijs L, Lodish HF. Tumor necrosis factor- $\alpha$ suppresses adipocyte-specific genes and activates expression of preadipocyte genes in 3T3-L1 adipocytes: Nuclear factor-kappaB activation by TNF- $\alpha$ is obligatory. Diabetes 2002;51:1319-36.

49. Gillman MW, Rifas-Shiman S, Berkey CS, Field AE, Colditz GA. Maternal gestational diabetes, birth weight, and adolescent obesity. Pediatrics 2003;111:e221-6.

50. Schaefer-Graf U, Pawliczak J, Passow D, et al. Birth weight and parental BMI predict overweight in children from mothers with gestational diabetes. Diabetes Care 2005;28:1745-50. 